Gut, 1980, 21, 324-328

\title{
Comparison of maximal acid output and gastrin response to meals in Chinese and Scottish normal and duodenal ulcer subjects
}

\author{
S K LAM, M HASAN, W SIRCUS, J WONG, G B ONG, \\ AND R J PRESCOTT \\ From the Departments of Medicine and of Surgery, University of Hong Kong, Queen Mary Hospital, \\ Hong Kong, the Gastrointestinal Unit, University of Edinburgh, Western General Hospital, Edinburgh, \\ and the Medical Computing and Statistics Unit, University of Edinburgh Medical School, Edinburgh
}

SUMMARY Maximal acid output (MAO) after pentagastrin stimulation and gastrin response to a standard meal was studied in 100 control and 200 duodenal ulcer subjects from each of two ethnic groups, Scots and Chinese. The acid output was significantly higher in the Scots than in the Chinese for both controls and duodenal ulcer patients. Despite correction for differences in body stature by expressing MAO as a function of the body weight, these differences persisted. In 45 pairs of closely matched patients with duodenal ulcer, the differences between the two ethnic groups remained significant, irrespective of whether MAO was expressed in absolute or weight corrected values. This indicates that differences in age, sex, family history, or duration of illness did not account for differences in acid output. In 20 pairs of normal control and 45 pairs of duodenal ulcer patients the fasting and post-prandial serum gastrin levels did not differ significantly between the two ethnic groups. The proportion of acid normosecretors was significantly higher in the Chinese duodenal ulcer patients than in the Scottish. The reason for these differences in the gastric acid output between the two ethnic groups is not known and needs to be studied further.

The pathophysiology of duodenal ulcer remains undefined. There is ample evidence that patients with duodenal ulcer as 'a group' secrete on average a higher amount of gastric acid than normal when stimulated by maximal doses of histamine acid phosphate or pentagastrin, but the individual levels of the two groups overlap each other widely. ${ }^{12}$ Two previous studies ${ }^{3}$ suggested that Chinese patients with duodenal ulcer had a small acid output upon stimulation by histamine acid phosphate or pentagastrin when compared with occidental subjects.

These two studies, however, can be regarded only as preliminary because the comparison was made with patients reported in the Western literature and a large number of factors that may affect acid secretion have not been taken into considerationnamely, age and sex, ${ }^{1}$ body weight, ${ }^{25}$ duration of ulcer symptoms, ${ }^{56}$ blood group status, ${ }^{2} 8$ family history of ulceration, ${ }^{910}$ complication by pyloro-

Received for publication 6 November 1979 duodenal stenosis, ${ }^{25}$ as well as a lack of uniformity in the methods used to measure acid secretion.

The present study examines the acid secretion in the context of these and some other factors in two ethnic groups of duodenal ulcer patients: Chinese and Scots.

\section{Methods}

PATIENTS

The data were obtained from a consecutive series of 200 duodenal ulcer patients attending hospital in Hong Kong and a similar consecutive series in Edinburgh, Scotland. They correspond to two of the series reported in another paper (unpublished data).

Duodenal ulcer was diagnosed by barium meal, endoscopy and/or subsequent surgery. Patients with pyloroduodenal stenosis were excluded from the study.

NORMAL CONTROLS

One hundred Chinese and 100 Scottish subjects acted as controls. These were recruited from among 
healthy medical staffs, students, technicians, and patients who had recovered from an unassociated illness such as pneumothorax or from a minor operation like herniorrhaphy. Informed consent was obtained from all subjects studied. These subjects also correspond to those reported by Prescott $e t$ al. (unpublished data) with the addition of 50 Scottish subjects in whom height was not recorded.

MAXIMUM ACID OUTPUT (MAO)

This was measured in all subjects. The methodology was conventional ${ }^{11}$ and is described in detail elsewhere (unpublished data).

\section{SERUM GASTRIN ESTIMATION}

This was carried out on a separate day in 20 pairs of normal controls and 45 pairs of duodenal ulcer patients (vide infra). Fasting started at 20.00 hours the day before. At 09.00 hours, a slow intravenous infusion of sodium chloride solution $(150 \mathrm{mmol} / \mathrm{l})$ was started. After the subject had rested for 15 minutes the first blood sample was taken (zero to 15 minutes) and 15 minutes later (zero time) another sample was taken, after which the patient ate a standardised meal consisting of $50 \mathrm{~g}$ protein, $40 \mathrm{~g}$ carbohydrate, and $40 \mathrm{~g}$ fat. For the Scots, the meal consisted of $20 \mathrm{~g}$ Casilan (protein hydrolysate) mixed with an instant breakfast powder with $6 \mathrm{~g}$ protein, $0.15 \mathrm{~g}$ fat, and $10 \mathrm{~g}$ carbohydrate and homogenised in $300 \mathrm{ml}$ of milk, together with $45 \mathrm{~g}$ of cheddar cheese and $10 \mathrm{~g}$ of butter. For the Chinese, the meal was in the form of a milk drink $(60 \mathrm{~g}$ Sustagen in $60 \mathrm{ml}$ of milk) and Chinese-style rice congee $(130 \mathrm{~g}$ of minced beef in $240 \mathrm{ml}$ of plain congee with $5 \mathrm{ml}$ of cooking oil). Additional blood samples were taken at $15,30,45,60$, and 90 minutes after the start of the meal. The serum from all samples was extracted by centrifugation immediately and stored at $-20^{\circ} \mathrm{C}$ for subsequent radioimmunoassay.

Gastrin estimations by radio-immunoassay were performed in duplicate with a modification of the method of Yalow and Berson. ${ }^{12}$ The details of the assay have been previously reported..$^{13}{ }^{14}$ Sensitivity was below $2.5 \mathrm{mmol} / 1$ of serum. Within assay and between assay coefficients of variation were 6.2 and
$13 \%$, respectively. The antiserum reacted equally with G17 and G34 gastrin. The data showed no significant skewness.

The MAO results are presented both as raw values and after standardisation by division by body weight (unpublished data), having shown that when MAO is regressed on weight the intercept on the $y$ axis does not differ significantly from zero. The integrated gastrin response after the standard meal $(\Sigma \mathrm{g})$ of each subject was derived by computing the total area under the response curve from zero to 90 minutes.

\section{MATCHING}

Twenty pairs of normal controls were selected from each race for comparison of gastrin secretion. Each pair was matched against sex and age to the nearest five years. Forty-five pairs of patients with duodenal ulcers were selected from each race for comparison of gastrin secretion. Each pair was matched against sex and age to the nearest five years. Forty-five pairs of patients with duodenal ulcers were selected from each race for comparison. These pairs were those giving a complete match with respect to sex, age to the nearest decade, duration of ulcer symptoms to the nearest five years, positivity of family history of ulcer dyspepsia, and blood group status. As well as giving the information on gastrin levels this set of 45 pairs was also used in comparing MAO levels.

\section{STATISTICAL ANALYSIS}

In the matched situation the paired $t$ test or McNemar's test ${ }^{15}$ were used as appropriate. Otherwise the $t$ test for independent samples of Chisquared tests was used.

\section{Results}

\section{NORMAL CONTROLS}

The mean age and sex distribution are shown in Table 1. Among Chinese subjects male and female did not differ significantly in their acid secretion, whether this was expressed in absolute values $(\mathrm{mmol} / \mathrm{h})$ or in relation to total body weight (TBW) (mmol/h per $\mathrm{kg}$ ). Among the Scots, however, males had a significantly higher acid output than females

Table 1 Chinese $v$ Scots: normal subjects, age and MAO in males and females (mean $\pm S D$ )

\begin{tabular}{|c|c|c|c|c|}
\hline & \multicolumn{2}{|l|}{ Chinese } & \multicolumn{2}{|l|}{ Scots } \\
\hline & Males & Females & Males & Females \\
\hline $\begin{array}{l}\text { No. } \\
\text { Age (yr) } \\
\text { MAO (mmol/h) } \\
\text { MAO (mmol/kg) }\end{array}$ & $\begin{array}{l}60 \\
41 \cdot 0 \pm 17 \cdot 0 \\
12 \cdot 9 \pm 5 \cdot 4 \\
0 \cdot 25 \pm 0 \cdot 10\end{array}$ & $\begin{array}{l}40 \\
48 \cdot 3 \pm 18 \cdot 6 \\
12 \cdot 5 \pm 6 \cdot 4 \\
0 \cdot 26 \pm 0 \cdot 12\end{array}$ & $\begin{array}{l}60 \\
39 \cdot 2 \pm 13 \cdot 9 \\
23 \cdot 3 \pm 9 \cdot 6 \\
0 \cdot 30 \pm 0 \cdot 10\end{array}$ & $\begin{array}{l}40 \\
45.8 \pm 13.0 \\
17.8 \pm 6.3 \\
0.29 \pm 0.09\end{array}$ \\
\hline
\end{tabular}


when this was expressed in absolute values $(P<0.01)$, but not so when the values were corrected for body weight. Between the two races, the acid output in absolute values was significantly higher in the Scots than in the Chinese $(P<0.001)$ and this holds for both sexes. Furthermore, the overall difference persisted, though to a less extent when the acid output was corrected for body weight $(P<0.01)$. The mean and standard deviation was $0.25 \pm 0.11$ $\mathrm{mmol} / \mathrm{h}$ per $\mathrm{kg}$ for the Chinese and $0.30 \pm 0.10$ for the Scots.

\section{ALL DUODENAL ULCER PATIENTS}

The mean age and sex distribution are shown in Table 2. The Chinese patients were, on average, younger than the Scots $(P<0.001)$. Among the Chinese patients the MAO between the two sexes was significantly different, whether this was expressed in absolute values $(P<0.001)$ or in relation to body weight $(\mathrm{P}<0.01)$. Among the Scottish patients, while this was so when MAO was expressed in absolute values $(\mathrm{P}<\mathbf{0 . 0 0 1 )}$, the difference disappeared when this was corrected for body weight. The differences between the two races were significant in both sexes and were so irrespective of whether maximum acid output was expressed in absolute or weight-corrected values $(\mathbf{P}<0.001)$. The differences in the age distributions partly accounts for the difference in acid output between the male and female Chinese, as MAO decreases with age. However, this is not a complete explanation. The difference in mean age between males and females is similar in both the Chinese and Scots, and yet the Chinese show a male-female difference in weightcorrected acid output which is significantly different from that seen in the Scots $(\mathbf{P}<0.05)$. The difference in the mean age of the Scots and the Chinese offers no explanation for their difference in levels of acid output.

MATCHED DUOdenal Patients (Table 3)

In the 45 pairs of closely matched patients with duodenal ulcer, the differences between the two races remained significant irrespective of whether acid output was expressed in absolute or weightcorrected values $(\mathrm{P}<0.001)$.
SERUM GASTRIN

In both the 20 pairs of normal controls (Table 4) and the 45 pairs of ulcer patients (Table 3) the fasting and post-prandial serum gastrin levels did not differ significantly between the two races.

\section{NORMOSECRETING AND HYPERSECRETING}

DUODENAL ULCER PATIENTS

Patients whose MAO corrected for body weight was higher than two standard deviations above the mean of the normal controls were considered as hypersecretors and those whose acid output was within these limits were normosecretors. Based on the 100 normal controls of the respective races the proportions of normosecretors and hypersecretors were determined among the 200 duodenal ulcers of each race as well as in the 45 pairs of matched patients. The proportion of normosecretors was significantly higher in the Chinese patients than in the Scottish. The same trend was still obvious in the $\mathbf{4 5}$ pairs of matched patients and the difference remains significant (Table 5).

Table 3 Chinese $v$ Scots: 45 pairs of matched patients, maximum acid output (MAO), fasting and post-prandial serum gastrin (mean $\pm S D)$

\begin{tabular}{lccl}
\hline Males & Chinese & Scots & \\
\hline AO (mmol/h) & $19.0 \pm 8.8$ & $35.3 \pm 14.4$ & $\mathrm{P}<0.001$ \\
MAO (mmol/h/kg) & $0.36 \pm 0.17$ & $0.56 \pm 0.23$ & $\mathrm{P}<0.001$ \\
$\begin{array}{l}\text { Fasting gastrin } \\
\quad(\mathrm{pmol} / \mathrm{l})\end{array}$ & $32.4 \pm 18.1$ & $30.8 \pm 14.4$ & $\mathrm{NS}$ \\
$\begin{array}{l}\text { Peak gastrin (pmol/l) } \\
\text { Integrated gastrin } \\
\quad(\mathrm{nmol} / \mathrm{min} / \mathrm{l})\end{array}$ & $\mathbf{8 9 . 3} \pm 46.7$ & $89.9 \pm 49.3$ & $\mathrm{NS}$ \\
& $6.3 \pm 2.3$ & $6.1 \pm 2.5$ & $\mathrm{NS}$ \\
\hline
\end{tabular}

Table 4 Chinese v Scots: 20 pairs, age and sex-matched normal subjects; fasting and post-prandial serum gastrin (mean $\pm S D)$

\begin{tabular}{lrr}
\hline & Chinese & \multicolumn{1}{c}{ Scots } \\
\hline Fasting gastrin $(\mathrm{pmol} / \mathrm{l})$ & $25 \cdot 6 \pm 12 \cdot 1$ & $34 \cdot 0 \pm 15 \cdot 7$ \\
Peak gastrin $(\mathrm{pmol} / \mathrm{l})$ & $59 \cdot 2 \pm 20 \cdot 1$ & $68 \cdot 7 \pm 21 \cdot 9$ \\
Integrated gastrin $(\mathrm{nmol} / \mathrm{min} / \mathrm{l})$ & $5 \cdot 1 \pm 1 \cdot 8$ & $5 \cdot 7 \pm 1 \cdot 8$ \\
\hline
\end{tabular}

Table 2 Chinese $v$ Scots: duodenal ulcers, age, and MAO in males and females (mean $\pm S D$ )

\begin{tabular}{|c|c|c|c|c|}
\hline & \multicolumn{2}{|l|}{ Chinese } & \multicolumn{2}{|l|}{ Scots } \\
\hline & Males & Females & Males & Females \\
\hline $\begin{array}{l}\text { No. } \\
\text { Age (yr) } \\
\mathrm{MAO} / \mathrm{mmol} / \mathrm{h} \\
\mathrm{MAO} / \mathrm{mmol} / \mathbf{h} / \mathbf{k g}\end{array}$ & $\begin{array}{l}143 \\
39 \cdot 8 \pm 15 \cdot 3 \\
21 \cdot 8 \pm 10 \cdot 1 \\
0 \cdot 43 \pm 0 \cdot 21\end{array}$ & $\begin{array}{l}57 \\
45 \cdot 9 \pm 18 \cdot 0 \\
17 \cdot 4 \pm 8 \cdot 2 \\
0 \cdot 35 \pm 0 \cdot 17\end{array}$ & $\begin{array}{l}149 \\
45 \cdot 9 \pm 13 \cdot 7 \\
34 \cdot 4 \pm 12 \cdot 5 \\
0 \cdot 51 \pm 0 \cdot 18\end{array}$ & $\begin{array}{l}51 \\
51 \cdot 3 \pm 12 \cdot 3 \\
27.9 \pm 9 \cdot 7 \\
0.52 \pm 0.19\end{array}$ \\
\hline
\end{tabular}


Table 5 Chinese $v$ Scots: percentage of normosecretors and hypersecretors in 200 duodenal ulcer patients and in 45 pairs of matched patients

\begin{tabular}{|c|c|c|c|c|}
\hline & \multicolumn{2}{|l|}{ All patients } & \multicolumn{2}{|c|}{ Matched patients } \\
\hline & 200 & 200 & 45 & 45 \\
\hline $\begin{array}{l}\text { Normosecretors } \\
\text { Hypersecretors }\end{array}$ & $\begin{array}{r}138(69.0 \%) \\
62(31.0 \%) \\
\chi\end{array}$ & $\begin{array}{l}103(51 \cdot 5 \%) \\
97(48 \cdot 5 \%) \\
5, \mathrm{P0} \cdot 01\end{array}$ & $\begin{array}{l}\text { McNemar's test } \\
\chi^{2}=4.8, P 0.05\end{array}$ & $\begin{array}{l}22(48.9 \%) \\
23(51 \cdot 1 \%) \\
\text { emar's test } \\
.8, \mathrm{P} 0.05\end{array}$ \\
\hline
\end{tabular}

\section{Discussion}

This study shows that MAO levels are lower in Chinese subjects than in Scots, both in patients with duodenal ulcer and controls. There are, of course, differences in stature between the races which could conceivably explain the differences in MAO levels. In a separate study standardisation by means of division of body weight was recommended (unpublished data). However, even after division by body weight, the above differences persist and are highly significant. The anomalous finding of different weight corrected MAO levels in male and female ulcer patients in the Chinese series but not in the Scottish series is not readily explained. Until confirmed elsewhere it may, perhaps, best be regarded as one of the chance 'significant' findings that inevitably occur from time to time.

The difference in MAO levels between the Scots and the Chinese was maintained in ulcer patients even after matching for sex, age, duration of symptoms, familial dyspepsia, blood group, and absence of pyloric stenosis. Fasting post-prandial serum gastrin concentrations are similar in the two races both in the normal controls and in the ulcer patients (Tables 3 and 4). These features in Chinese duodenal ulcer patients could be due to a lesser degree of stimulation or 'drive' upon both gastrin and parietal cells than is the case with Scots. Alternatively, the primary feature may be a smaller gastrin cell mass in Chinese with a consequent degree of lowering of the trophic stimulus to the parietal cells.

It is of interest that duodenal ulcer appears in the Chinese in association with a lower acid secretory capacity than it does in Scots. The proportion of normosecreting ulcer patients, defined as those whose weight-corrected maximum acid output is within two standard deviations of the mean of the normal controls is significantly greater in the Chinese than in the Scottish patients. Furthermore, the parietal cell mass (PCM) of resected Chinese stomachs ${ }^{4}$ appeared to be smaller when compared with that of the resected Scottish stomachs reported by Card and Marks. ${ }^{16}$ In both studies the size of the PCM was linearly related to the maximum acid output. It thus appears that, while more than twothirds of the Chinese patients have a relatively normal PCM, only half of the Scottish patients have such. Whether environmental factors such as dietary habits and different genetic structure account for the racial differences remains to be determined.

The reasons for the occurrence of duodenal ulceration in acid normosecretors remain uncertain. Previous studies indicate that normosecretors have higher post-prandial gastrin response ${ }^{17}$ than hypersecretors. They respond equally in acid output as do the hypersecretors when they are psychically stimulated by food teasing ${ }^{18}$ and their pentagastrinstimulated acid output is more resistant than that of the hypersecretors to cholinergic inhibition. ${ }^{20}$ It is possible, therefore, that the pathophysiology of patients with ulcer disease and normosecretion may be different from that underlying the disease in acid hypersecretors.

The results from matching for age, sex, age of onset, duration of dyspepsia, etc. indicate that the difference between the two races in the proportion of normosecretors and hypersecretors is not simply due to earlier reference to hospital of the Chinese patients.

There is evidence of a trophic drive on the parietal cell mass exerted through the hypothalamus-vagal axis $^{20}$ and by circulating gastrin. ${ }^{2122}$ In this study we did not find differences between the races in fasting and post-prandial plasma gastrin levels.

It may be that the parietal cell mass in Scots is more responsive than in Chinese to an otherwise equal trophic force. Alternatively, there may be differences between ethnic groups in the ability to respond to inappropriate secretion of acid by an increase in the neutralising capability of $\mathrm{HCO}_{3}$ secretion or by morphological adaptation in the duodenal mucosa rendering it more resistant to proteolytic autodigestion. These factors have yet to be reported.

\section{References}

${ }^{1}$ Baron JH. Studies of basal and peak acid output with an augmented histamine test. Gut 1963; 4: 136-44. 
${ }^{2}$ Lam SK, Sircus W. Studies on duodenal ulcer I. The clinical evidence for the existence of two populations. Q J Med 1975; 44: 369-87.

${ }^{3}$ Fung, WP. Gastric acid secretion in Chinese with particular reference to the dose of histamine required for maximal stimulation. Gut 1970; 11: 955-61.

${ }^{4}$ Cheng FCY, Lam SK, Ong GB. Maximum acid output to graded doses of pentagastrin and its relation to parietal cell mass in Chinese patients with duodenal ulcer. Gut 1977; 18 : 827-32.

${ }^{5}$ Sircus W. Gastric secretion in peptic ulcer disease with special reference to the influence of body weight, duration of disease and stenosis. In: Semb LS, Myren J, eds. Physiology of gastric secretion. Oslo: Universitetsforlaget, 1968: 581-91.

${ }^{6}$ Hobsley M, Whitfield PF, Faber RG, Parkin JV. Hypersecretion and length of history in duodenal ulceration. Lancet 1975; 2 : 101-4.

'Buckwalter JA, Wohlwend EB, Colter DC, Tidrick RT, Knowler LA. Peptic ulceration and ABO blood. JAMA 1956; 162: 1215-20.

${ }^{8}$ Vesely KT, Kubíčková Z, Dvořáková M. Clinical data and characteristics differentiating types of peptic ulcer. Gut 1968; 9: 57-68.

${ }^{9}$ Fodor O, Vestea S, Urcan S, et al. Hydrochloric acid secretion capacity of the stomach as an injerited factor in the pathogenesis of duodenal ulcer. Am J Dig Dis 1968; 13: 260-5.

${ }^{10}$ Artem'ev EN, Vil'dt MO, Potiakina NN, Musnitskaia EN. The importance of the hereditary factor in the pathogenesis of peptic ulcer. (Russian.) Sov Med 1970; 33 (4): 54-8.

${ }^{11 B a r o n ~} \mathrm{JH}$. The clinical application of gastric secretion measurements. Clin Gastroenterol 1973; 2: 293-314.

${ }^{12}$ Yalow RS, Berson SA. Radioimmunoassay of gastrin. Gastroenterology 1970; 58: 1-14.

${ }^{13}$ Byrnes DJ, Lam SK, Sircus W. The relationship between functioning parietal cell and gastrin cell masses in two groups of duodenal ulcer patients. Clin Sci Mol Med 1956; 50: 375-83.

${ }^{14}$ Lam SK, Lai CL. Inhibition of sulpiride on the cephalic phase of gastric acid and gastrin secretion in duodenal ulcer patients. Scand J Gastroenterol 1976; 11: 27-31.

${ }^{15} \mathrm{McNemar} Q$. Note on the sampling error of the difference between correlated proportions or percentages. Psychometrika 1974; 12: 153-7.

${ }^{16}$ Card WI, Marks IN. The relationship between the acid output of the stomach following 'maximal' histamine stimulation and the parietal cell mass. Clin Sci 1960; 19: $147-63$.

${ }^{17}$ Lam SK, Sircus W. A comparison of the acid and gastrin secretory responses to hypoglycaemia and meals in duodenal ulcer with and without acid hypersecretion to pentagastrin. Digestion 1976; 14: 1-11.

${ }^{18}$ Lam SK, Sircus W. Vagal hyperactivity in duodenal ulcer: with and without excessive acid secretion. Rendiconti di Gastroenterologia 1975; 7: 5-9.

${ }^{19}$ Lam SK, Sircus W. Cholinergic suppression of the acid response to pentagastrin in normosecreting and hypersecreting duodenal ulcer patients. Rendiconti di Gastroenterologia 1977; 9: 9-12.

${ }^{20}$ Leonard AS, Gilsdorf RB, Pearl JM, Peter ET, Ritchie WP. Hypothalamic influence on gastric blood flow, cell counts, acid and mucus secretion-factors in ulcer provocation. In: Shnitka TK, Gilbert JA, Harrison RC, eds. Gastric secretion: mechanisms and control. Oxford: Pergamon Press, 1967; 149-74.

${ }^{21}$ Martin F, Macleod IB, Sircus W. Effects of antrectomy on the fundic mucosa of the rat. Gastroenterology 1970; 59: 437-44.

${ }^{22}$ Crean GP, Marshall MW, Rumsey RDE. Parietal cell hyperplasia induced by the administration of pentagastrin (ICI 50, 123) to rats. Gastroenterology 1969; 57: 147-55. 